\title{
Pathogenic Characterization of Genotypes A and B of Phialophora gregata f. sp. sojae
}

T. J. Hughes, Former Graduate Research Assistant, Department of Plant Pathology, University of WisconsinMadison, 1630 Linden Drive, Madison, 53706; W. Chen, Professor, Illinois Natural History Survey and Department of Crop Science, University of Illinois at Urbana-Champaign, 607 East Peabody Drive, Champaign, 61820; and C. R. Grau, Professor, Department of Plant Pathology, University of Wisconsin-Madison, 1630 Linden Drive, Madison, 53706

\begin{abstract}
Hughes, T. J., Chen, W., and Grau, C.R. 2002. Pathogenic characterization of genotypes A and B of Phialophora gregata f. sp. sojae. Plant Dis. 86:729-735.

Genetic studies of Phialophora gregata f. sp. sojae, the causal agent of brown stem rot (BSR) of soybean, have led to the development of species-specific primers capable of separating isolates into two distinct genotypes, A and B. To determine whether genotypic characterization could be related to differences in BSR symptom expression, five soybean cultivars, Pioneer 9234, Corsoy 79 (both BSR susceptible), Williams, BSR 101, and Jack and plant introduction (PI) 437970 (all BSR resistant), were inoculated with a total of 27 isolates of each genotype in four greenhouse experiments conducted from February to November 2000. BSR severity was calculated as the percentage of symptomatic foliar, internal stem, and internal root tissue. Genotype A isolates caused significantly more severe $(P<0.0001)$ BSR foliar symptoms than genotype B isolates on Pioneer 9234, Corsoy 79, Williams, and BSR 101, while Jack and PI 437970 expressed minimal foliar symptoms regardless of isolate genotype. Overall, internal stem symptoms caused by genotype A isolates were more severe than those caused by genotype B isolates on Pioneer 9234, Corsoy 79, Williams, and BSR 101. Conversely, Jack and PI 437970 did not differ significantly in severity of stem symptoms when inoculated with isolates of genotype A or B. Internal root symptoms for genotype A isolates were generally more severe than for genotype B isolates on all soybean genotypes tested. Our data strongly suggest that A and B genotypes of $P$. gregata f. sp. sojae differ in the severity of symptoms they cause, and that these genotypes correspond to the Type I (defoliating) and Type II (nondefoliating), respectively, pathotypes previously proposed for this vascular pathogen of soybean.
\end{abstract}

Additional keywords: brown stem rot, Glycine max, pathogen variation, Plectosporium tabacinum, soybean disease, vascular disease

Phialophora gregata (Allington \& Chamberlain) W. Gams f. sp. sojae, Kobayashi, Yamamoto, Negishi and Ogoshi (18), the causal agent of brown stem rot (BSR) of soybean (Glycine max (L.) Merr), is an economically significant pathogen of soybean in the north-central United States (32). Symptoms associated with BSR include browning of the vascular and pith tissues of the stem and root (internal symptoms), which may be accompanied by a sudden interveinal chlorosis and necrosis and wilting of the leaves (foliar symptoms), appearing approximately 3 weeks before physiological maturity (23). Yield losses of $30 \%$ or more are common when both foliar and internal stem symptoms are produced $(10,23)$, and yield differences between a resistant and a suscep-

Corresponding author: T. J. Hughes

E-mail: tjhughes@wsu.edu

Accepted for publication 20 February 2002.

Publication no. D-2002-0422-02R

(C) 2002 The American Phytopathological Society tible cultivar range between 10.6 (3) and $17 \%$ (24). Yield differences between a resistant and a susceptible cultivar are substantially less when only the internal symptoms are expressed $(3,23)$.

Influences of environment $(11,23,26,29)$, soybean cultivar $(2,21,23)$, and pathogen variability $(10,11,28,31)$ on symptom development of BSR have been studied. Incidence and severity of both foliar and internal symptoms are favored by temperatures between 15 and $27^{\circ} \mathrm{C}$ (12) and high soil moisture after flowering (23). Isolates of $P$. gregata f. sp. sojae vary in the types of symptoms produced (internal and foliar versus internal only) and in their severity. In 1971, Gray (9) characterized different pathotypes of $P$. gregata $\mathrm{f}$. sp. sojae based on whether an isolate caused both foliar and internal symptoms or internal symptoms only, and designated these pathotypes as Type I (defoliating) and Type II (nondefoliating), respectively. Mengistu and Grau (22) and Mengistu et al. (25) support these designations while Harrington et al. (15) proposed that the nondefoliating (Type II) isolates may have been misidentified isolates of Plectosporium tabacinum (van
Beyma) M.E. Palm (teleomorph Plectosphaerella cucumerina (Lindf.) Kleb). Plectosporium tabacinum is a fungus commonly isolated from soybean tissue, and is morphologically similar to $P$. gregata f. sp. sojae. However, the role of Plectosporium tabacinum in modifying soybean health has not been established $(6,7,22)$.

Several studies have been conducted to identify genetic differences among isolates of $P$. gregata f. sp. sojae. Isozyme banding patterns (22), restriction fragment length polymorphisms (RFLP) patterns of mitochondrial DNA (13), and sequencing of the internal transcribed spacer region (ITS) of the ribosomal DNA (rDNA) $(6,7)$ have successfully separated $P$. gregata f. sp. sojae from other soybean infecting fungi, including Plectosporium tabacinum. Unfortunately, these studies were unable to identify genetic variation among isolates of P. gregata f. sp. sojae.

Recently, Chen et al. (5), using the intergenic spacer region (IGS) located between rDNA transcription units, identified a region of variability among isolates of $P$. gregata f. sp. sojae, and developed two specific primers capable of separating isolates through polymerase chain reaction (PCR) into distinct genotypes A (1,020 bp) and $\mathrm{B}(830 \mathrm{bp})$. Primers were specific to isolates of $P$. gregata. No PCR product was obtained when DNA from nine other soybean-infecting fungi, including Plectosporium tabacinum, were used in PCR reaction with these primers (5). Primers were used to characterize isolates obtained from soybeans and to detect $P$. gregata f. sp. sojae genotype A or B directly from soybean stems collected throughout seven Midwestern states, Canada, and Brazil. From this survey, it was observed that genotypes $\mathrm{A}$ and $\mathrm{B}$ were present across a range of fields and environments. Genotype A isolates were isolated at a higher frequency that genotype B isolates from soybean cultivars susceptible to BSR, while genotype $\mathrm{B}$ isolates were isolated at a higher frequency than genotype A isolates from cultivars resistant to BSR. Additionally, the original isolate of $P$. gregata $\mathrm{f}$. sp. sojae (ATTC 11073), identified as a Type II (nondefoliating) isolate (9), belonged to the B genotype (5). The objective of this study was to determine if genotypic 
characterization of $P$. gregata f. sp. sojae isolates was related to differences in BSR symptom development based on the severity of foliar and internal stem symptoms.

\section{MATERIALS AND METHODS}

Fifty-four isolates of $P$. gregata f. sp. sojae, 27 genotype $\mathrm{A}$, and 27 genotype $\mathrm{B}$ were obtained from the isolate collection of Weidong Chen, Urbana, IL, and were selected to represent a range of geographical areas and cultivars from which isolates were obtained (Table 1). Except for isolates ATTC 11073, ATTC 38594, ATTC 44011, H96-5, and OH2 isolates were obtained from infected soybean stems between 1994 and 1998 as previously described (5). Stock cultures consisted of agar plugs from 2-week-old cultures on green bean agar stored in sterile distilled

Table 1. Designation and origin of Phialophora gregata f. sp. sojae isolates

\begin{tabular}{|c|c|c|c|c|}
\hline \multirow[b]{2}{*}{ Isolate } & \multirow[b]{2}{*}{ Genotype $^{a}$} & \multicolumn{3}{|c|}{ Origin } \\
\hline & & Location & Germplasm & BSR rxn ${ }^{b}$ \\
\hline $98 \mathrm{~A} 1-1-2^{\text {cdef }}$ & A & Illinois & BSR 101 & $\mathrm{R}$ \\
\hline $98 D 9-2-2^{\text {ef }}$ & A & Wisconsin & BSR 101 & $\mathrm{R}$ \\
\hline $98 B 7-2^{\text {cdef }}$ & A & Wisconsin & Archer & $\mathrm{R}$ \\
\hline $98 \mathrm{C} 1-5^{\text {cdef }}$ & A & Wisconsin & Sturdy & $\mathrm{S}$ \\
\hline $98 \mathrm{~F} 1-9^{\mathrm{cd}}$ & A & Wisconsin & Pioneer 9305 & $\mathrm{~S}$ \\
\hline $98 \mathrm{G} 1-3^{\text {cdef }}$ & A & Illinois & Unknown & $\ldots$ \\
\hline A4- $1^{\text {cd }}$ & A & Illinois & Kaltenberg KB241 & $\mathrm{S}$ \\
\hline B $1-5-2^{\mathrm{cd}}$ & A & Wisconsin & $\mathrm{S} 24-92$ & $\mathrm{~S}$ \\
\hline B2-2 $2^{\text {cd }}$ & $\mathrm{A}$ & Wisconsin & Sturdy & $\mathrm{S}$ \\
\hline $\mathrm{B} 3-7^{\mathrm{cd}}$ & A & Wisconsin & Sturdy & $\mathrm{S}$ \\
\hline $\mathrm{C} 3-2-2^{\mathrm{cd}}$ & A & Wisconsin & BSR 101 & $\mathrm{R}$ \\
\hline $\mathrm{F} 4-5-2 \mathrm{G}^{\mathrm{cd}}$ & A & Illinois & Century 86 & $\mathrm{~S}$ \\
\hline $\mathrm{F} 5-3^{\mathrm{cd}}$ & A & Illinois & LN92-12033 & $\mathrm{R}$ \\
\hline F7-5C $\mathrm{C}^{\mathrm{cd}}$ & A & Illinois & Dekalb CX313 & $\mathrm{S}$ \\
\hline Fulton-OH ${ }^{c d}$ & A & Ohio & Unknown & $\ldots$ \\
\hline $\mathrm{G} 3^{\mathrm{cd}}$ & A & Illinois & Unknown & $\ldots$ \\
\hline $\mathrm{M} 2^{\mathrm{ef}}$ & A & Michigan & Unknown & $\ldots$ \\
\hline H96-5 $5^{\text {cdef }}$ & A & Wisconsin & Corsoy 79 & $\mathrm{~S}$ \\
\hline $\mathrm{IN}^{\mathrm{cd}}$ & A & Indiana & Unknown & $\ldots$ \\
\hline $\operatorname{Mn} 10^{\mathrm{cd}}$ & A & Minnesota & Unknown & $\ldots$ \\
\hline $\mathrm{M} 4^{\mathrm{cd}}$ & A & Michigan & Unknown & $\ldots$ \\
\hline $\mathrm{OH} 2^{\text {cd }}$ & $\mathrm{A}$ & Ohio & Unknown & $\ldots$ \\
\hline $\mathrm{On} 2^{\mathrm{cd}}$ & A & Ontario & Unknown & $\ldots$ \\
\hline $\mathrm{P} 266^{\mathrm{cd}}$ & $\mathrm{A}$ & Iowa & Unknown & $\ldots$ \\
\hline P361-1 ${ }^{\mathrm{cd}}$ & A & Iowa & Unknown & $\ldots$ \\
\hline $\mathrm{S} 4-1^{\mathrm{cd}}$ & A & Illinois & Seiben SS282N & $\mathrm{R}$ \\
\hline $98 \mathrm{~F} 1-4^{\mathrm{cd}}$ & A & Illinois & Pioneer 9305 & $\mathrm{~S}$ \\
\hline $98 \mathrm{~A} 5-6^{\mathrm{cdef}}$ & $\mathrm{B}$ & Illinois & LN92-12033 & $\mathrm{R}$ \\
\hline $98 \mathrm{~B} 1-6^{\mathrm{cd}}$ & $\mathrm{B}$ & Wisconsin & BSR 101 & $\mathrm{R}$ \\
\hline $98 \mathrm{~B} 3-1^{\text {cdef }}$ & $\mathrm{B}$ & Wisconsin & PI 437833 & $\mathrm{R}$ \\
\hline $98 B 4-1^{\text {cdef }}$ & $\mathrm{B}$ & Wisconsin & PI 437833 & $\mathrm{R}$ \\
\hline $98 \mathrm{~B} 4-2^{\mathrm{cd}}$ & $\mathrm{B}$ & Wisconsin & PI 437970 & $\mathrm{R}$ \\
\hline $98 \mathrm{~B} 4-3^{\text {cdef }}$ & $\mathrm{B}$ & Wisconsin & PI 437970 & $\mathrm{R}$ \\
\hline $98 \mathrm{~F} 1-7^{\mathrm{cd}}$ & $\mathrm{B}$ & Illinois & Pioneer 9305 & $\mathrm{~S}$ \\
\hline $98 \mathrm{~A} 5-3^{\mathrm{ef}}$ & $\mathrm{B}$ & Illinois & LN92-12033 & $\mathrm{R}$ \\
\hline $98 \mathrm{~A} 4-2^{\mathrm{ef}}$ & B & Illinois & PI 437970 & $\mathrm{R}$ \\
\hline B $1-2-2^{c}$ & $\mathrm{~B}$ & Wisconsin & Seiben SS24-92 & $\mathrm{S}$ \\
\hline B $1-6-2^{\text {cd }}$ & B & Wisconsin & Seiben SS24-92 & $\mathrm{S}$ \\
\hline $\mathrm{C} 2-2-2^{\mathrm{cd}}$ & $\mathrm{B}$ & Wisconsin & Hardin & $\mathrm{S}$ \\
\hline $\mathrm{F} 1-2^{\mathrm{cd}}$ & $\mathrm{B}$ & Illinois & LN92-12033 & $\mathrm{R}$ \\
\hline $\mathrm{F} 2-3^{\mathrm{cd}}$ & $\mathrm{B}$ & Illinois & LN95-12054 & $\mathrm{S}$ \\
\hline F3-2-2 ${ }^{\text {cd }}$ & $\mathrm{B}$ & Illinois & IA 3003 & $\mathrm{R}$ \\
\hline $\mathrm{F} 5-2^{\mathrm{cd}}$ & $\mathrm{B}$ & Illinois & LN92-12033 & $\mathrm{R}$ \\
\hline IN5 ${ }^{\mathrm{cd}}$ & $\mathrm{B}$ & Indiana & Unknown & $\ldots$ \\
\hline $\mathrm{M} 1^{\mathrm{cd}}$ & $\mathrm{B}$ & Michigan & Unknown & $\ldots$ \\
\hline $\mathrm{M} 3^{\mathrm{cd}}$ & $\mathrm{B}$ & Michigan & Unknown & $\ldots$ \\
\hline $\mathrm{S} 2-1^{\text {cdef }}$ & $\mathrm{B}$ & Illinois & Seiben SS282N & $\mathrm{R}$ \\
\hline $\mathrm{S} 3-3^{\mathrm{cd}}$ & $\mathrm{B}$ & Illinois & Seiben SS282N & $\mathrm{R}$ \\
\hline S5 $-5^{\text {cdef }}$ & B & Illinois & Seiben SS282N & $\mathrm{R}$ \\
\hline ATTC $11073^{\mathrm{cd}}$ & $\mathrm{B}$ & Missouri & Unknown & $\ldots$ \\
\hline ATTC 38594d & $\mathrm{B}$ & Unknown & Unknown & $\ldots$ \\
\hline ATTC $44011^{\mathrm{cd}}$ & B & Iowa & Unknown & $\ldots$ \\
\hline $98 \mathrm{~B} 3-2^{\mathrm{cd}}$ & $\mathrm{B}$ & Wisconsin & PI 437833 & $\mathrm{R}$ \\
\hline $\mathrm{F} 2-8-2^{\mathrm{cd}}$ & $\mathrm{B}$ & Illinois & LN92-12054 & $\mathrm{S}$ \\
\hline $\mathrm{F} 3-8^{\mathrm{cd}}$ & B & Illinois & IA 3003 & $\mathrm{R}$ \\
\hline
\end{tabular}

a Determined by Chen et al. (5).

b Brown stem rot reaction of soybean germplasm. $\mathrm{R}=$ resistant; $\mathrm{S}=$ susceptible.

c Isolate used in experiment 1.

d Isolate used in experiment 2.

e Isolate used in experiment 3.

${ }^{\mathrm{f}}$ Isolate used in experiment 4.

water at $4^{\circ} \mathrm{C}(5)$. Working cultures of each isolate were maintained on potato dextrose agar (100 g peeled, sliced potatoes, $5 \mathrm{~g}$ dextrose, $6 \mathrm{~g}$ agar, and $500 \mathrm{ml}$ of distilled water) at $16^{\circ} \mathrm{C}$. With only a few exceptions (Table 1), each isolate was evaluated in at least two different experiments. Four of the isolates used in these experiments, 98A11-2, S4-1, 98B3-1, and S2-1 have been deposited in the American Type Culture Collection and given the following identifiers, ATCC MYA-733, ATCC MYA-732, ATCC MYA-735, and ATCC MYA-734, respectively.

A total of four experiments were conducted between February and November 2000 at two locations on the University of Wisconsin-Madison campus. Location 1 greenhouses (experiments 1 and 3) were programmed with 14-h photoperiods, supplemented by high-pressure sodium lamps with daytime/nighttime temperatures at 22 and $18^{\circ} \mathrm{C}$, respectively. Location 2 greenhouses (experiments 2 and 4 ) averaged 14$\mathrm{h}$ photoperiods, supplemented by highpressure sodium lamps, and temperatures between 23 and $27^{\circ} \mathrm{C}$.

Spore suspensions of each isolate were prepared in 250-ml flasks containing 100 $\mathrm{ml}$ of green bean broth ( $40 \mathrm{~g}$ Gerber, Fremont, Michigan, "2nd Foods" green beans plus $500 \mathrm{ml}$ of distilled water). Flasks were inoculated with two to three plugs of mycelium obtained from the margin of an actively growing culture and placed on a rotary shaker at $130 \mathrm{rpm}$ for approximately 10 days. Spores and mycelial fragments were counted using a hemacytometer, and the inoculum density was adjusted to $5 \times$ $10^{6}$ spores and mycelium per $\mathrm{ml}$ with sterile distilled water immediately prior to inoculation.

In experiments 1 and 2, seeds of soybean cvs. Jack (BSR-resistant) and Corsoy 79 (BSR-susceptible) were germinated in medium grade vermiculite in $25.4 \times 50.8$ $\mathrm{cm}$, 96-well flats, containing commercial grade Bradyrhizobium japonicum (Kirchner) Jordan (Nitragin Inoculants, Liphatech Inc., Milwaukee, WI). Seedlings were inoculated approximately 2 weeks after seeding, at the VC-V1 growth stage (unifoliate leaves fully expanded) using a modified root dip method (27). Nine uniformly healthy seedlings of each cultivar were removed from the vermiculite, and the roots rinsed with tap water. Roots were trimmed so that 3 to $4 \mathrm{~cm}$ of root remained below the root-stem interface. The seedlings were then placed in a $250-\mathrm{ml}$ plastic beaker containing inoculum of a single isolate for $20 \mathrm{~min}$. The procedure was repeated for 25 genotype A, 25 genotype B isolates (Table 1), and each soybean cultivar. Control plants were mock inoculated in the same method using sterilized distilled water.

Immediately after inoculation, seedlings were transplanted to $15.24-\mathrm{cm}$-diameter plastic pots containing a 1:1 mixture of 
steam-pasteurized soil (1:1 field soil and sand) and Fafard (Anderson, SC) growing medium (location 1) or Scott's (Marysville, $\mathrm{OH})$ Metro Mix (location 2) with additional B. japonicum. Each treatment (cultivar $\times$ isolate) was replicated three times with three plants per pot. Pots were arranged in a completely randomized blocked design. Plants were fertilized 1 week after inoculation with approximately eight grams per pot of Osmocote 18-6-12 (one time) and then weekly with Peter's 20-20-20. Plants were grown for approximately 6 to 7 weeks until the R2 growth stage (full flowering). Each plant per pot was then rated for BSR symptom severity by visually estimating the percentage of symptomatic foliar tissue and the percentage of internal stem and tap root showing browning of the vascular and pith tissues when split longitudinally, and assigning a Horsfall-Baratt (HB) rating where: $0=0 \%$; $1=0$ to $3 \% ; 2=3$ to $6 \% ; 3=6$ to $12 \% ; 4$ $=12$ to $25 \% ; 5=25$ to $50 \% ; 6=50$ to $75 \% ; 7=75$ to $88 \% ; 8=88$ to $94 \% ; 9=94$ to $97 \% ; 10=97$ to $100 \%$; and $11=100 \%$
(16). Ratings were converted to percentages for analysis using conversion tables from Elanco Products (Divison of Eli Lilly, Indianapolis, IN). Ratings for the three plants per pot were averaged, and the means analyzed in an analysis of variance (ANOVA) using the PROC GLM procedure of the SAS statistical analytical software system (SAS Institute, Cary, NC). Statistical significance was determined at the $5 \%$ level of probability $(P=$ $0.05)$.

In experiment 3 , six soybean genotypes, Corsoy 79, Pioneer 9234 (both BSRsusceptible), Jack, Williams, BSR 101, and plant introduction (PI) 437970 (all BSRresistant) and in experiment 4 , four soybean cvs. Corsoy 79, Pioneer 9234, Jack, and Williams, were challenged with seven genotype A and eight genotype B isolates (Table 1) to confirm the results of experiments 1 and 2 across different soybean genotypes. All methods, including experimental design and data analysis for experiments 3 and 4 , followed those used for experiments 1 and 2.

\section{RESULTS}

ANOVA of BSR symptom severity revealed a highly significant cultivar, pathogen genotype, and cultivar $\times$ pathogen genotype effects for foliar symptom expression in all four experiments (Tables 2 and 3). Similar effects were observed for internal stem symptom expression in three of four experiments. Significant cultivar, genotype, and cultivar $\times$ genotypes effects for internal root symptom expression were highly variable across all experiments.

BSR-susceptible cvs. Corsoy 79 and Pioneer 9234 and BSR-resistant cvs. Williams and BSR 101, expressed significantly more severe $(P<0.0001)$ foliar symptoms when inoculated with genotype A isolates than genotype $B$ isolates in all four experiments (Figs. 1 to 3). BSRresistant cv. Jack and PI 437970 expressed minimal foliar symptoms regardless of isolate genotype. Overall, differences in internal symptom severity caused by either genotype A or B isolates for the five cultivars and one PI tested were less consistent than those differences observed for foliar

Table 2. Analysis of variance for brown stem rot symptom severity caused by genotype A and B isolates of Phialophora gregata f. sp. sojae

\begin{tabular}{|c|c|c|c|c|c|c|c|c|}
\hline \multirow[b]{2}{*}{ Source } & \multicolumn{4}{|c|}{ Greenhouse experiment 1} & \multicolumn{4}{|c|}{ Greenhouse experiment 2} \\
\hline & df & MS & $F$ value & $P>F$ & df & MS & $F$ value & $P>F$ \\
\hline \multicolumn{9}{|l|}{ Foliar } \\
\hline Cultivar & 1 & $51,051.6$ & 190.69 & 0.0001 & 1 & $87,319.9$ & 182.82 & 0.0001 \\
\hline Genotype & 1 & $42,929.2$ & 160.35 & 0.0001 & 1 & $39,033.6$ & 81.72 & 0.0001 \\
\hline Cultivar $\times$ genotype & 1 & $41,727.2$ & 155.86 & 0.0001 & 1 & $29,928.0$ & 62.66 & 0.0001 \\
\hline Replicate (blocks) & 2 & 262.2 & 0.98 & 0.3767 & 2 & $1,749.2$ & 3.66 & 0.0269 \\
\hline Error & 294 & 267.7 & $\ldots$ & $\ldots$ & 294 & 477.6 & $\ldots$ & $\ldots$ \\
\hline \multicolumn{9}{|l|}{ Stem } \\
\hline Cultivar & 1 & $33,521.7$ & 79.71 & 0.0001 & 1 & $44,298.9$ & 109.05 & 0.0001 \\
\hline Genotype & 1 & $18,118.1$ & 43.08 & 0.0001 & 1 & 0.1 & 0.00 & 0.9856 \\
\hline Cultivar $\times$ genotype & 1 & $25,724.3$ & 61.17 & 0.0001 & 1 & $1,021.9$ & 2.52 & 0.1138 \\
\hline Replicate (blocks) & 2 & $1,243.6$ & 2.96 & 0.0535 & 2 & $1,445.2$ & 3.56 & 0.0297 \\
\hline Error & 294 & 420.52 & $\ldots$ & $\ldots$ & 294 & 406.2 & $\ldots$ & $\ldots$ \\
\hline \multicolumn{9}{|l|}{ Root } \\
\hline Cultivar & 1 & $17,144.6$ & 20.64 & 0.0001 & 1 & $3,417.9$ & 4.29 & 0.0392 \\
\hline Genotype & 1 & $31,915.6$ & 38.41 & 0.0001 & 1 & $5,492.1$ & 6.90 & 0.0091 \\
\hline Cultivar $\times$ genotype & 1 & 264.5 & 0.32 & 0.5730 & 1 & 3.4 & 0.00 & 0.9478 \\
\hline Replicate (blocks) & 2 & 799.4 & 0.96 & 0.3833 & 2 & 990.3 & 1.24 & 0.2899 \\
\hline Error & 294 & 830.8 & $\ldots$ & $\ldots$ & 294 & 796.5 & $\ldots$ & $\ldots$ \\
\hline
\end{tabular}

Table 3. Analysis of variance for brown stem rot symptom severity caused by genotype A and B isolates of Phialophora gregata f. sp. sojae

\begin{tabular}{|c|c|c|c|c|c|c|c|c|}
\hline \multirow[b]{2}{*}{ Source } & \multicolumn{4}{|c|}{ Greenhouse experiment 3} & \multicolumn{4}{|c|}{ Greenhouse experiment 4} \\
\hline & df & MS & $F$ value & $P>F$ & df & MS & $F$ value & $P>F$ \\
\hline \multicolumn{9}{|l|}{ Foliar } \\
\hline Cultivar & 5 & $4,814.0$ & 25.48 & 0.0001 & 3 & $1,670.9$ & 12.06 & 0.0001 \\
\hline Genotype & 1 & $29,388.2$ & 155.58 & 0.0001 & 1 & $4,939.6$ & 35.66 & 0.0001 \\
\hline Cultivar $\times$ genotype & 5 & $5,419.2$ & 28.69 & 0.0001 & 3 & $1,600.4$ & 11.55 & 0.0001 \\
\hline Replicate (blocks) & 2 & 683.2 & 3.62 & 0.0282 & 2 & 21.8 & 0.16 & 0.8547 \\
\hline Error & 256 & 188.9 & $\ldots$ & $\ldots$ & 170 & 138.5 & $\ldots$ & $\ldots$ \\
\hline \multicolumn{9}{|l|}{ Stem } \\
\hline Cultivar & 5 & 757.4 & 9.35 & 0.0001 & 3 & $2,339.5$ & 27.35 & 0.0001 \\
\hline Genotype & 1 & $1,708.0$ & 21.09 & 0.0001 & 1 & $2,244.8$ & 26.24 & 0.0001 \\
\hline Cultivar $\times$ genotype & 5 & 395.4 & 4.88 & 0.0003 & 3 & $1,134.6$ & 13.26 & 0.0001 \\
\hline Replicate (blocks) & 2 & 81.1 & 1.00 & 0.3687 & 2 & 283.7 & 3.32 & 0.0386 \\
\hline Error & 256 & 81.0 & $\ldots$ & $\ldots$ & 170 & 85.5 & $\ldots$ & $\ldots$ \\
\hline \multicolumn{9}{|l|}{ Root } \\
\hline Cultivar & 5 & $2,114.3$ & 6.99 & 0.0001 & 3 & 510.3 & 1.26 & 0.2907 \\
\hline Genotype & 1 & 28.0 & 0.09 & 0.7612 & 1 & $11,715.7$ & 28.87 & 0.0001 \\
\hline Cultivar $\times$ genotype & 5 & 956.4 & 3.19 & 0.0082 & 3 & 367.8 & 0.91 & 0.5757 \\
\hline Replicate (blocks) & 2 & 886.1 & 2.93 & 0.0553 & 2 & 224.8 & 0.55 & 0.4393 \\
\hline Error & 256 & 302.6 & $\ldots$ & $\ldots$ & 170 & 405.8 & $\ldots$ & $\ldots$ \\
\hline
\end{tabular}


symptom severity. Cultivars for which genotype A isolates caused significantly more severe foliar symptoms than genotype B isolates (Corsoy 79, Pioneer 9234, Williams, and BSR 101), also expressed more severe stem symptoms when inoculated with genotype A isolates than genotype B isolates. However, differences in stem symptoms were not significant for all experiments (Figs. 1 to 3 ). Jack and PI 437970 expressed only minor differences in severity of foliar and stem symptoms regardless of isolate genotype (Figs. 1 to 3). For most soybean genotypes tested, internal root symptom severity was generally less severe for plants inoculated with genotype $\mathrm{B}$ isolates than genotype A isolates. The reverse was observed one time for Corsoy 79 and Pioneer 9234 (Fig. 2).

\section{DISCUSSION}

The results of this study strongly suggest that genotypic characterization of $P$. gregata f. sp. sojae isolates is related to differences in BSR symptom expression. Results suggest that genotypes A and B correspond to the Type I (defoliating) and Type II (nondefoliating), respectively, pathotypes characterized by Gray in 1971 (9).

Individually, isolates of the B genotype were capable of causing some level of foliar symptoms, though none caused more than $12 \%$ disease severity (data not shown). The foliar symptoms caused by genotype B isolates were limited to a slight, interveinal chlorosis, with little or no necrosis, which did not ascend above the third node (second trifoliate leaf). Furthermore, the foliar symptoms caused by genotype B isolates were not associated with either wilting or defoliation. In the original report of the Type I and Type II classification, Gray (9) described the Type II isolates as nondefoliating or as nonwilt inducing. There was no mention as to whether the Type II isolates were incapable of causing minimal chlorosis or necrosis. Additionally, successive studies conducted by Gray $(10,11)$ always employed the genotype B isolate, ATTC 11073, of $P$. gregata $\mathrm{f}$. sp. sojae to represent the Type II (nondefoliating) isolate which, in accord with our results, did not cause chlorosis, necrosis, wilting, or defoliation (data not shown). Therefore, it is proposed that the definition of the Type II isolates be redefined to include those isolates that can cause minimal foliar symptoms, but no defoliation or wilting, on a BSRsusceptible cultivar.

Harrington et al. (15) suggested that the Type II isolates observed in previous stud- ies $(9,22,25)$ might have been misidentified isolates of the fungus Plectosporium tabacinum. In their study, they examined seven isolates of $P$. gregata f. sp. sojae on two soybean cultivars, one resistant and one susceptible to BSR. They concluded that all seven isolates caused foliar symptoms characteristic of BSR and therefore, none could be characterized as a Type II isolate. Consequently they proposed, that the terms "nondefoliating" and "Type II" might not be appropriate for isolates of $P$. gregata (15). It may well be that there were no Type II (nondefoliating) isolates among their test strains due to a limited sample size or origin of the isolate (5). However, this does not preclude the existence of the Type II pathotype in P. gregata f. sp. sojae. On the other hand, two of the seven isolates studied, produced significantly less severe foliar symptoms on the BSR susceptible cv. Kenwood in addition to less severe stem symptoms. In comparing the results from our study to those of Harrington et al. (15) and using the revised definition of a Type II isolate, it is possible that the two isolates that caused significantly less severe foliar symptoms, belong to the B genotype and concomitantly, are isolates of the Type II pathotype. Harrington et al. (15) raised valid concerns that now can be

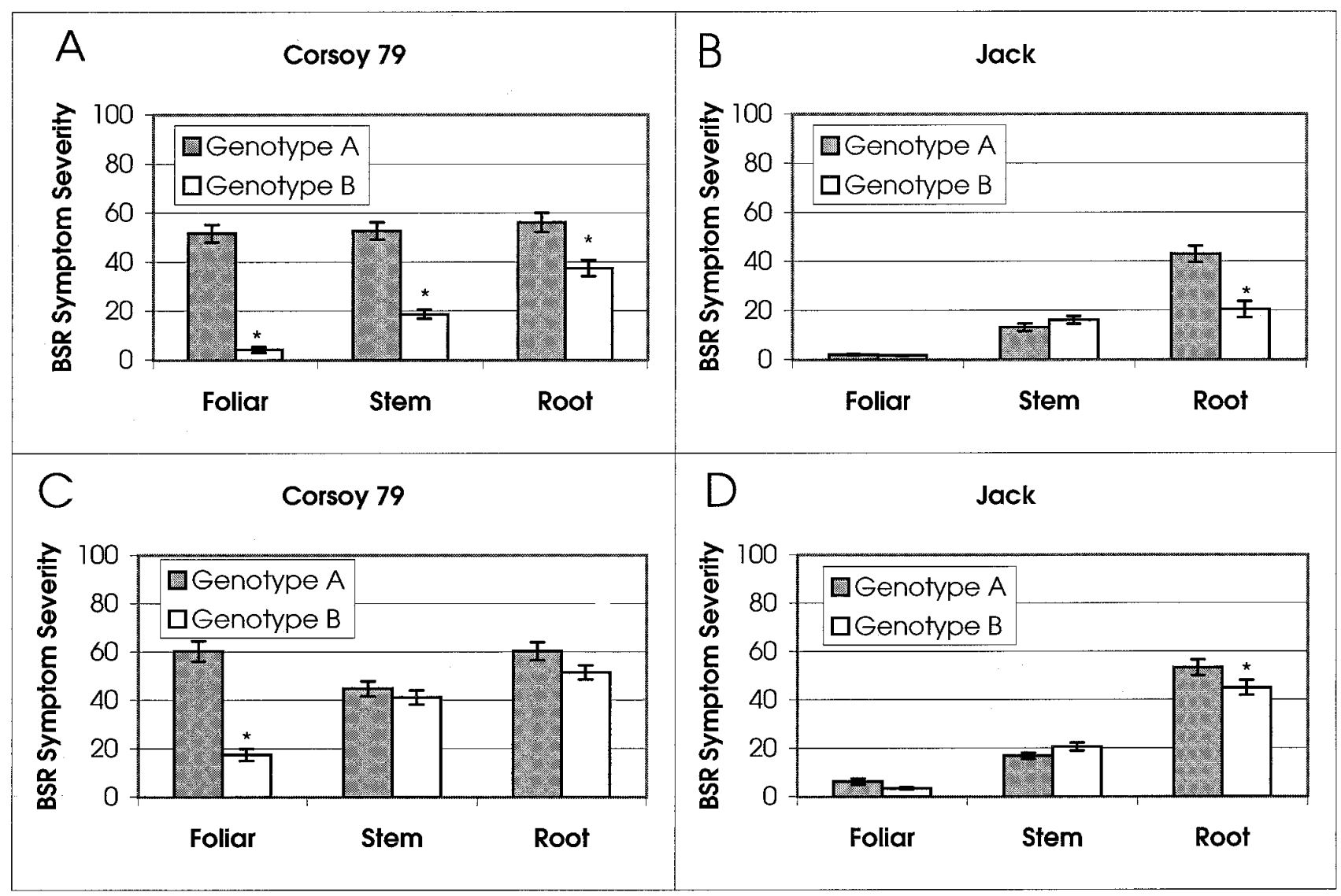

Fig. 1. Percent foliar, internal stem, and internal root tissues symptomatic of brown stem rot (BSR) for soybean cvs. Corsoy 79 (BSR-susceptible) and Jack (BSR-resistant) inoculated with either genotype A or genotype B isolates of Phialophora gregata f.sp. sojae. A, Corsoy 79 for greenhouse experiment 1. B, Jack for greenhouse experiment 1. C, Corsoy 79 for greenhouse experiment 2. D, Jack for greenhouse experiment 2. Values are means of three replications. Bars represent standard error of the mean. Means marked by an asterisk $\left(^{*}\right)$ indicate significant differences at $P=0.05$. 
addressed by characterizing isolates of $P$. gregata f. sp. sojae for both genotype (5) and pathotype $(9, \mathrm{~W}$. Chen, personal communication).

The higher internal stem symptom severity for BSR-susceptible cultivars inoculated with genotype A isolates is consistent with the results observed by Gray (9) and Mengistu and Grau (22) for Type I isolates. Furthermore, Gray noted that BSRresistant PI 84946-2 expressed less severe internal stem symptoms when inoculated with either Type I or Type II isolates when compared to BSR-susceptible cv. Clark-63.
In our study, we observed that soybean genotypes resistant to BSR development also expressed less severe internal stem symptoms, regardless of isolate genotype, when compared to susceptible Corsoy 79 and Pioneer 9234. However, differences were observed among the four resistant soybean genotypes in regards to symptom severity caused by either genotype A or B. Genotype A isolates caused significantly more severe stem symptom severity than genotype B isolates on cvs. Williams and BSR 101, while genotype B isolates caused slightly more severe stem symptoms than genotype A isolates on cv. Jack and PI 437970 .

Differences in BSR symptom severity among the four BSR-resistant soybean genotypes may be attributed to differences in resistant genes. Three loci, designated Rbs 1 (14), Rbs 2 (14), Rbs 3 (30), have been identified as locations of alleles that confer resistance to BSR development. $\mathrm{Cv}$. BSR 101 contains the Rbs 1 and $R b s 3$ loci (8) and PI 437970 contains the Rbs 3 locus (30). The resistance in cvs. Jack and Williams has yet to be identified. Current genetic mapping studies suggest that the

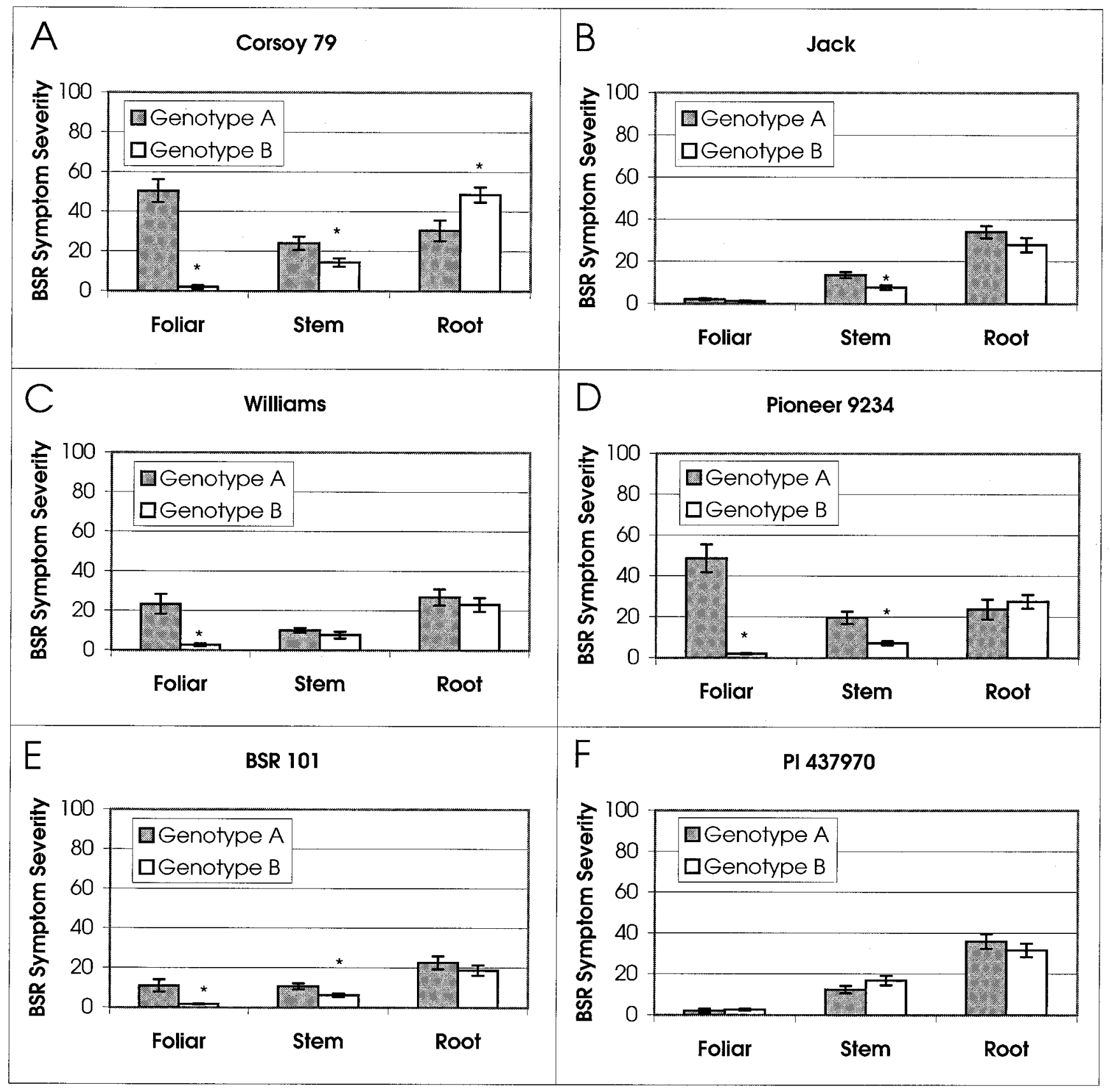

Fig. 2. Percent foliar, internal stem, and internal root tissues symptomatic of brown stem rot (BSR) for soybean cvs. Corsoy 79, Pioneer 9234, Jack, Williams, BSR 101, and plant introduction (PI) 437970 inoculated with either genotype A or genotype B isolates of Phialophora gregata f.sp. sojae for greenhouse experiment 3. A, Corsoy 79 (BSR-susceptible). B, Jack (BSR-resistant). C, Williams (BSR-resistant). D, Pioneer 9234 (BSR-susceptible). E, BSR 101 (BSR-resistant). F, PI 437970 (BSR-resistant). Values are means of three replications. Bars represent standard error of the mean. Means marked by an asterisk $(*)$ indicate significant differences at $P=0.05$. 
gene(s) for BSR resistance in Jack may be located within the same region of the soybean linkage group $\mathrm{J}$ as $R b s \mathrm{1}, R b s \mathrm{2}$, and Rbs 3 (4,20, B. Diers, personal communication). Williams, a parent of Jack, has been hypothesized to contain one or more genes for BSR-resistance (T. Hughes, B. Diers, S. Carlson, N. Kurtzweil and C. Grau, unpublished data) but genetic identification of these genes has not yet been done.

Greenhouse experiments evaluating soybean genotypes for resistance to BSR development against a single, genotype A isolate of $P$. gregata $\mathrm{f}$. sp. sojae (H96-5), indicate that cvs. BSR 101 and Williams express similar levels of resistance to BSR based on severity of foliar symptoms. ( $\mathrm{T}$. Hughes, B. Diers, S. Carlson, N. Kurtzweil and C. Grau, unpublished data). Likewise, cv. Jack and PI 437970 show similarities in BSR foliar symptom severity. These data suggest that cvs. BSR 101 and Williams share similar genes for resistance to BSR that are different from the resistance genes shared by cv. Jack and PI 437970.

The differences observed for both foliar and internal stem symptom severity among the four BSR-resistant soybean genotypes inoculated with either genotype A or B isolates supports the cultivar $\times$ isolate in- teraction reported by Willmot et al. (31). Additionally, Willmot et al. (31) proposed that differing isolates of $P$. gregata $\mathrm{f}$. sp. sojae might serve as useful tools for distinguishing different mechanisms of host resistance and identifying resistant genes. Therefore, it is suggested that isolates of both genotypes A and B may benefit breeders interested in identifying stronger or more stable sources of resistance and to researchers studying the inheritance of BSR resistance genes and mechanisms of resistance they govern.

This study provides genotypic data to support the Type I and Type II pathotype designations within $P$. gregata f. sp. sojae. Previous work (17) has shown that isolates of genotypes A and B cannot be differentiated based on cultural phenotype (i.e., colony morphology, sporulation, and growth rate). Nor do isolates of either genotype inhibit the growth of one another or exhibit anastomosis in vitro (T. J. Hughes, unpublished data). Currently, studies are being conducted to determine how BSR symptom development in the field relates to the presence of either genotype A or B in soybean tissue and the distribution of each genotype within a given field. Information from this study and those currently being conducted may help to explain the variation among fields, geographic locations, and cultivar reaction between field and greenhouse studies in regards to BSR development. Preliminary data show that fields where little or no BSR foliar symptom expression occurs, regardless of soybean genotype or environmental conditions, are on the whole, associated with isolates of the B genotype. Further research is needed to determine if preferential host infection (5), saprophytic survival and population densities (1), and soil $\mathrm{pH}$ (19) impact the distribution of A and B genotypes of $P$. gregata $\mathrm{f}$. sp. sojae. Knowledge within these areas may help predict the disease potential within a specific field, aid breeders and researchers in selecting fields for experimentation, and benefit our understanding of how different management practices can be used to control BSR development.

\section{ACKNOWLEDGMENTS}

Special thanks to L. E. Gray and N. C. Kurtzweil for their insight, comments, and suggestions throughout the course of this research. This research was funded by the University of Wisconsin-Madison, College of Agriculture and Life Sciences (CALS), Hatch project number 4244.

\section{LITERATURE CITED}

1. Adee, E. A., Grau, C. R., and Oplinger, E. S. 1997. Population dynamics of Phialophora

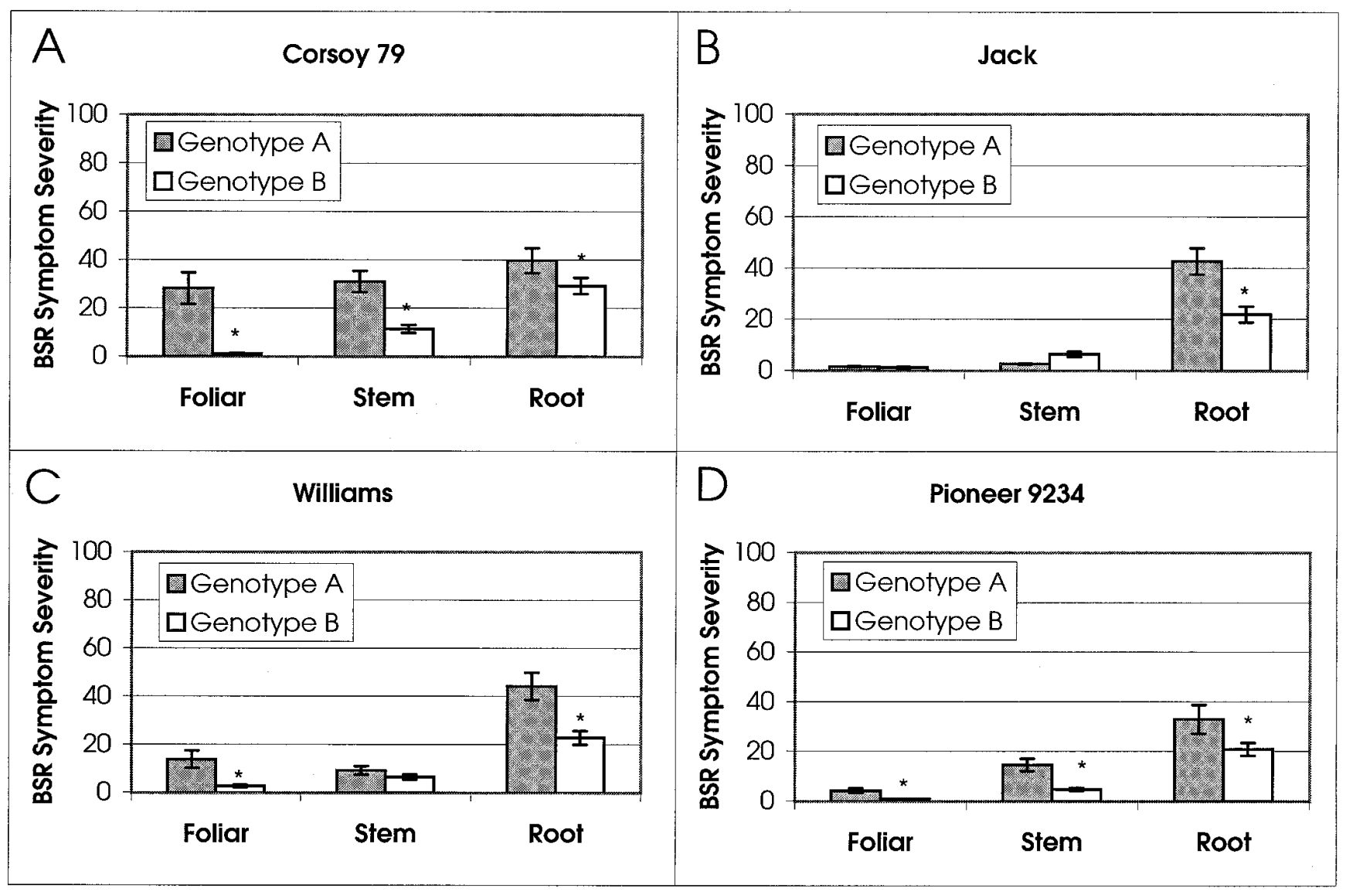

Fig. 3. Percent foliar, internal stem, and internal root tissues symptomatic of brown stem rot (BSR) for soybean cvs. Corsoy 79, Pioneer 9234, Jack, and Williams inoculated with either genotype A or genotype B isolates of Phialophora gregata f.sp. sojae for greenhouse experiment 4 . A, Corsoy 79 (BSRsusceptible). B, Jack (BSR-resistant). C, Williams (BSR-resistant). D, Pioneer 9234 (BSR-susceptible). Values are means of three replications. Bars represent standard error of the mean. Means marked by an asterisk $(*)$ indicate significant differences at $P=0.05$. 
gregata in soybean residue. Plant Dis. 81:199-203

2. Adee, E. A., Oplinger, E. S., and Grau, C. R. 1994. Tillage, rotation sequence, and cultivar influences on brown stem rot and soybean yield. J. Prod. Agric. 7:341-347.

3. Bachman, M. S., Nickell, C. D., Stephens, P. A., Nickell, A. D., and Gray, L. E. 1997. The effect of $R b s 2$ on yield of soybean. Crop Sci. 37:1148-1151.

4. Bachman, M. S., Tamulonis, J. P., Nickell, C. D., and Bent, A. F. 2001. Molecular markers linked to brown stem rot resistance genes, $R b s$ 1 and $R b s$ 2, in soybean. Crop Sci. 41:527535 .

5. Chen, W., Grau, C. R., Adee, E. A., and Meng, X.-Q. 2000. Molecular marker identifying subspecific populations of the soybean brown stem rot pathogen, Phialophora gregata. Phytopathology 90:875-883.

6. Chen, W., Gray, L. E., and Grau, C. R. 1996. Molecular differentiation of fungi associated with brown stem rot and detection of Phialophora gregata in resistant and susceptible soybean cultivars. Phytopathology 86:11401148.

7. Chen, W., Gray, L. E., Kurle, J. E., and Grau, C. R. 1999. Specific detection of Phialophora gregata and Plectosporium tabacinum in infected soybean plants using polymerase chain reaction. Mol. Ecol. 8:871-887.

8. Eathington, S. R., Nickell, C. D., and Gray, L. E. 1995. Inheritance of brown stem rot resistance in soybean cultivar BSR 101. J. Hered. 86:55-60.

9. Gray, L. E. 1971. Variation in pathogenicity of Cephalosporium gregatum isolates. Phytopathology 61:1410-1411.

10. Gray, L. E. 1972. Effect of Cephalosporium gregatum on soybean yield. Plant Dis. Rep. 56:580-581.

11. Gray, L. E. 1974. Role of temperature, plant age, and fungus isolate in the development of brown stem rot in soybeans. Phytopathology 64:94-96.
12. Gray, L. E., and Grau, C. R. 1999. Brown stem rot. Pages 28-29 in: Compendium of Soybean Diseases. 4th ed. G. L. Hartman, J. B. Sinclair, and J. C. Rupe, eds. The American Phytopathological Society, St. Paul, MN.

13. Gray, L. E., and Hepburn, A. G. 1992. Mitochondrial DNA restriction patterns of Phialophora gregata isolates from soybean and adzuki bean. Phytopathology 82:211-215.

14. Hanson, P. M., Nickell, C. D., Gray, L. E., and Sebastian, S. A. 1988. Identification of two dominate genes conditioning brown stem rot resistance in soybean. Crop Sci. 28:41-43.

15. Harrington, T. C., Steimel, J., Workneh, F., and Yang, X. B. 2000. Molecular identification of fungi associated with vascular discoloration of soybean in the North Central United States. Plant Dis. 84:83-89.

16. Horsfall, J. G., and Barratt, R. W. 1945. An improved grading system for measuring plant disease. (Abstr) Phytopathology 35:655.

17. Hughes, T. J., Chen, W., Grau, C. R., and Kurtzweil, N. C. 2000. Phenotypic variation within and among genotypically different isolates of Phialophora gregata. (Abstr) Phytopathology 90:S37.

18. Kobayashi, K., Yamamoto, H., Nigishi, H., and Ogoshi, A. 1991. Formae speciales differentiation of Phialophora gregata isolates from adzuki bean and soybean in Japan. Ann. Phytopathol. Soc. Jpn. 57:255-231.

19. Kurtzweil, N. C., and Grau, C. R. 2001. Relationship of soil $\mathrm{pH}$ and brown stem rot of soybean. (Abstr) Phytopathology 9:S178.

20. Lewers, K. S., Crane, E. H., Bronson, C. R., Schupp, J. M., Keim, P., and Shoemaker, R. C. 1999. Detection of linked QTL for soybean brown stem rot resistance in BSR 101 as expressed in a growth chamber environment. Mol. Breed. 5:33-42.

21. Meese, B. G., Carter, P. R., Oplinger, E. S., and Pendleton, J. W. 1991. Corn/soybean rotation effect as influenced by tillage, nitrogen, and hybrid/cultivar. J. Prod. Agric. 4:74-80
22. Mengistu, A., and Grau, C. R. 1986. Variation in morphological, cultural, and pathological characteristics of Phialophora gregata and Acremonium sp. recovered from soybean in Wisconsin. Plant Dis. 70:1005-1009.

23. Mengistu, A., and Grau, C. R. 1987. Seasonal progress of brown stem rot and its impact on soybean productivity. Phytopathology 77:1521-1529.

24. Mengistu, A., Grau, C. R., and Gritton, E. T. 1986. Comparison of soybean genotypes for resistance to and agronomic performance in the presence of brown stem rot. Plant Dis. 70:1095-1098.

25. Mengistu, A., Tachibana, H., and Grau, C. R. 1991. Selective media for the isolation and enumeration of Phialophora gregata from soybean straw and soil. Plant Dis. 75:196 199.

26. Schneider, R. W., Sinclair, J. B., and Gray, L. E. 1972. Etiology of Cephalosporium gregatum in soybean. Phytopathology 62:345-349.

27. Sebastian, S. A., Nickell, C. D., and Gray, L. E. 1983. Sequential screening of soybean plants for resistance to Phytophthora rot and brown stem rot. Crop Sci. 23:1214-1215.

28. Sills, G. R., Grittion, C. R., and Grau, C. R. 1991. Differential reaction of soybean genotypes to isolates of Phialophora gregata. Plant Dis. 75:687-690.

29. Waller, R. S., Nickell, C. D., and Gray, L. E. 1992. Environmental effects on the development of brown stem rot in soybean. Plant Dis. 76:454-457.

30. Willmot, D. B., and Nickell, C. D. 1989 Genetic analysis of brown stem rot resistance in soybean. Crop Sci. 29:672-674.

31. Willmot, D. B., Nickell, C. D., and Gray, L. E. 1989. Physiologic specialization of Phialophora gregata on soybean. Plant Dis. 73:290294.

32. Wrather, J. A., Stienstra, W. C., and Koenning, S. R. 2001. Soybean disease loss estimates for the United States from 1996 to 1998. Can. J. Plant Pathol. 23:122-131. 